[Agr. Biol. Chem., Vol. 32, No. 8, p. 929 939, 1968]

\title{
Biochemical Studies on $\alpha$-Glucosidase from Buckwheat (Fagopyrum esculentum Mönch)
}

\author{
Part II. Purification of Buckwheat $\alpha$-Glucosidase \\ and Some Properties on Maltose \\ and Soluble Starch*
}

By Miho Takahashi and Tokuji Shimomura

Department of Agricultural Chemistry, Faculty of Agriculture, Hokkaido University, Sapporo

Received October 11, 1967

\begin{abstract}
Buckwheat $\alpha$-glucosidase was purified approximately 300 -fold by CM-cellulose treatment, calcium phosphate gel treatment, fractionation with ammonium sulfate, chromatography on a column of calcium phosphate gel and CM-Sephadex treatment. The purified $\alpha$-glucosidase showed one peak ultracentrifugally but was heterogeneous in moving-boundary electrophoresis.

The enzyme hydrolyzed not only maltose but also soluble starch, and glucose was the sole product from both substrates. At a lower substrate concentration $(0.5 \%)$, the rate of the initial reaction with maltose was about 3 times higher than that with soluble starch. At higher substrate concentrations $(2.5 \%$ and $5 \%)$ the enzyme showed a trans-glucosylase action toward both substrates.

The following properties were perfectly identical on maltose and soluble starch; optimum $\mathrm{pH} 5.0$; optimum temperature, ca. $52^{\circ} \mathrm{C}$; range of $\mathrm{pH}$ stability, $4 \sim 7.3$; temperature of stability, $45^{\circ} \mathrm{C}$ for $10 \mathrm{~min}$; enzymatic activity on each substrate, almost lost at $60^{\circ} \mathrm{C}$ for $30 \mathrm{~min}$.
\end{abstract}

It was shown in the preceding paper ${ }^{1 /}$ that buckwheat seed possessed a high $\alpha$-glucosidase activity and especially ungerminated seed was suitable for the preparation of a plant $\alpha$-glucosidase. The present investigation was undertaken to purify the $\alpha$-glucosidase from buck wheat seed and to determine some properties of this enzyme.

Many attempts to purify $\alpha$-glucosidase have been made on yeast, ${ }^{2 \sim 61}$ molds $^{7 \sim 101}$ and ani-

* This report was presented at the Annual Meeting of the Agricultural Chemical Society of Japan, Tokyo, April 1, 1967.

1) M. Takahashi and T. Shimomura, Agr. Biol. Chem., 32, (1968).

2) H. Halvorson and L. Ellias, Biochem. Biophys. Acta, 30, 28 (1958).

3) A. W. Phillips, Arch. Biochem. Biophys., 80, 346 (1959). mals. ${ }^{11,12} \quad$ A few of these $\alpha$-glucosidases were separated in crystalline forms ${ }^{9,10)}$ or as a homogeneous protein in ultracentrifugal analysis, ${ }^{3 \prime}$ but most of them were only partially purified and their properties were examined by using

4) G. Terui, H. Okada and Y. Oshima, Symp, on Enzyme Chem. Japan, 14, 390 (1960).

5) S. Chiba, S. Sugawara, T. Shimomura and Y. Nakamura, Agr. Biol. Chem., 26, 787 (1962).

6) S. Chiba and T. Shimomura, ibid., 29, 540 (1965).

7) K. Kitahara and U. Murata, J. Ferment. Tech., 32, 473 (1954).

8) T. Matsushima, $J$. Biochem., 47, 830 (1960).

9) S. Sugawara, Y. Nakamura and T. Shimomura, Agr. Biol. Chem., 23, 156 (1959).

10) Y. Tsujisaka and J. Fukumoto, Nippon Nogeikagaku Kaishi, 37, 668 (1963).

11) I. Lieberman and W.H. Eto, J. Biol. Chem., 225, 899 (1957).

12) A. Dahlquist, Acta Chem. Scand., 13, 1817 (1957). 
crude enzyme preparations. Regarding plant $\alpha$-glucosidase, little attention has been directed toward their purification and properties. However, more recently, information about several kinds of plant $\alpha$-glucosidase has been provided: Hutson and Manners ${ }^{13}$ have reported the presence of maltase and nigerase activities in alfalfa and tomato preparations; Jørgensen and Jørgensen ${ }^{14 !}$ have reported on the purification and properties of $\alpha$-glucosidase from malted barley; Akimoto and Shimomura ${ }^{15}$ obtained a homogeneous $\alpha$-glucosidase preparation from rice seeds; and Kasugai ${ }^{161}$ separated an amylase preparation with $\alpha$-glucosidase activity from mung bean sprouts.

From the results of the present investigation it has been found that purified buckwheat $\alpha$-glucosidase hydrolyzed not only maltose, but also soluble starch to glucose and in the presence of high concentrations of both substrates, transglucosylation activity was clearly recognized. It is of interest to note that most ${ }^{14 \sim 16)}$ of plant $\alpha$-glucosidases described above show the similar hydrolytic activities toward both maltose and soluble starch and also exhibit transglucosylative activities.

\section{MATERIALS AND METHODS}

Materials. Buckwheat seeds used for enzyme purification were produced in Hokkaido in 1965. Maltose (Difco. Laboratory) and soluble starch (Kanto Kagaku Co., guaranteed reagent) were obtained from commercial sources.

Measurement of enzymatic activity. Enzymatic activity was estimated from the amount of glucose produced in a reaction mixture by a modification of Somogyi's copper reagent method as described in Part I.1) In the course of purification of the enzyme solution, a reaction mixture containing $2 \mathrm{ml}$ of $1 \%$ maltose or $1 \%$ soluble starch, $1.9 \mathrm{ml}$ of $0.1 \mathrm{M}$ acetate buffer $(\mathrm{pH} 5.0)$ and $0.1 \mathrm{ml}$ of the enzyme solution

13) D. H. Hutson and D. J. Manners, Biochem. J., 94, 783 (1965).

14) B. B. Jorgensen and O. B. Jørgensen, Acta Chem. Scand., 17, 1765 (1963); O. B. Jørgensen, ibid., 17, 2471 (1963); ibid., 18, 53, 1115, 1975 (1964).

15) F. Akimoto and T. Shimomura, Memoirs of the Fac. Agr. Hokkaido Univ., 6, No. 3, (in press).

16) I. Kasugai, private letter. was incubated for $10 \mathrm{~min}$ at $37^{\circ} \mathrm{C}$. One unit of enzymatic activity on maltose was expressed as the amount of enzyme which hydrolyzed $1 \mu$ mole of maltose per minute under the conditions described above. The protein content was measured by optical density (OD) at $280 \mathrm{~m} \mu$. It is known that an OD at $280 \mathrm{~m} \mu$ of 1.0 corresponds to about $1 \mathrm{mg}$ of protein per $\mathrm{ml}, 17)$ when a cuvette with $1 \mathrm{~cm}$ light path is used. Specific activity was defined as maltase units per $\mathrm{OD}$ at $280 \mathrm{~m} \mu$. In the experiments in which final purified enzyme solution was used, the reaction condition is described in each case.

In any case, the determination of the reaction product was made under the experimental conditions where the degree of hydrolysis of maltose was below $50 \%$ and that of soluble starch, below 20\%, because the reaction was found to proceed linearly below these respective degrees of hydrolysis.

Electrophoretic analysis. Moving-boundary electrophoresis was performed with a Tiselius type Hitachi Model HTB-2 apparatus at $10^{\circ} \mathrm{C}$.

Ultracentrifugal analysis. Ultracentrifugal analysis was performed with a Spinco Model E ultracentrifuge.

Paper chromatography of sugars. Paper chromatography was carried out on Tôyō Roshi No. 50 filter paper by multiple ascending technique (three times). The solvent system was $n$-butanol-pyridine-water $(6: 4: 3)$, and the sugars were detected with anisidine phthalate spray reagent ${ }^{18}$, at $110^{\circ} \mathrm{C}$ for $5 \mathrm{~min}$.

\section{RESULTS AND DISCUSSION}

\section{Purification of buckwheat $\boldsymbol{a}$-glucosidase}

Buckwheat seeds were pulverized and the hull was removed. Thirty $\mathrm{kg}$ of the powder was extracted with 140 liters of $0.1 \mathrm{M}$ acetate buffer ( $\mathrm{pH} \mathrm{5.0)}$ at room temperature for $5 \mathrm{hr}$ under slow stirring. After 15 min centrifugation at $3000 \mathrm{rpm}$ the supernatant (A), 134 liters, was treated with a minimum volume of $1 \%$ rivanol, 6 liters, which precipitated contaminated mucilage but not enzyme protein. The filtrate obtained, 140 liters, was adsorbed on carboxymethyl (CM)-cellulose, $400 \mathrm{~g}$, without removing rivanol with kaolin, because the latter caused an irreversible adsorption of this

17) T. Kobayashi "Jikken Kagaku Köza", Maruzen press, Japan (1958), Vol. 24, p. 40.

18) A. Schweizer, J. Chromato., 9, 374 (1962). 
enzyme. The adsorbate was extracted with $0.5 \mathrm{M}$ acetate buffer ( $\mathrm{pH} \mathrm{5.0)}$ and the extract (B), 26 liters, was fractionated with ammonium sulfate ( 0.65 saturation). The aqueous solution of the resulting precipitate was dialyzed against running tap water at $10 \sim 11^{\circ} \mathrm{C}$. The dialysate (C), 5.1 liters, was adjusted to $\mathrm{pH} 5.0$ and treated with calcium phosphate gel and the adsorbent was washed with distilled water, followed by extraction with $0.5 \mathrm{M}$ phosphate buffer ( $\mathrm{pH}$ 7.2). The extract (D), 8.7 liters, was adjusted to $\mathrm{pH} 5.0$ and refractionated with ammonium sulfate $(0.4 \sim 0.7$ saturation) and the resulting precipitate was dissolved in distilled water. Then the enzyme solution was dialyzed against tap water and filtered. The filtrate (E), $97 \mathrm{ml}$, was dialyzed against $0.1 \mathrm{~m}$ phosphate buffer $(\mathrm{pH} 6.81)$ at $4^{\circ} \mathrm{C}$ and a portion of the enzyme solution, $20 \mathrm{ml}$, was applied to a column $(3.3 \times 5 \mathrm{~cm})$ of calcium phosphate gel mixed with cellulose powder. After the column was washed with $0.1 \mathrm{~m}$ phosphate buffer ( $\mathrm{pH} 6.81$ ), the adsorbed component was eluted with $0.2 \mathrm{M}$ and $0.5 \mathrm{M}$ phosphate buffer ( $\mathrm{pH}$ 6.81). As shown in Fig. 1, maltase activity was found in fractions of both Peak I and Peak II. The remaining enzyme solution was treated in several portions with the same procedure. Fractions corresponding to Peak I (for instance, fraction No. $49 \sim 75$ in Fig. 1) and Peak II (for instance, fraction No. 110 117 in Fig. 1) were combined together separately. Each combined fraction $(F)$ was dialyzed against $0.1 \mathrm{M}$ acetate buffer $(\mathrm{pH} 5.0)$ and adsorbed on a CM-Sephadex column $(1.5 \times 6 \mathrm{~cm})$ equilibrated with the same buffer to concentrate the enzyme solution. The elution was performed with $0.5 \mathrm{~m}$ acetate buffer $(\mathrm{pH}$ 5.0) containing $0.1 \mathrm{M} \mathrm{NaCl}$ and the eluates were dialyzed against $0.1 \mathrm{M}$ phosphate buffer ( $\mathrm{pH} 6.81$ ) at $4^{\circ} \mathrm{C}$. Rechromatography on calcium phosphate gel was further tried for each of these two enzyme solutions in order to separate Peak I from Peak II more clearly. As a result, either enzyme solution was separated into two peaks again, as shown in Fig. 2-(I) and (II). Then, fractions (No. 100 175) of the first peak in Fig. 2-(I) and fractions (No. 75 155) of the first peak in Fig. 2-(II) were combined together and the combined fraction was chromato-

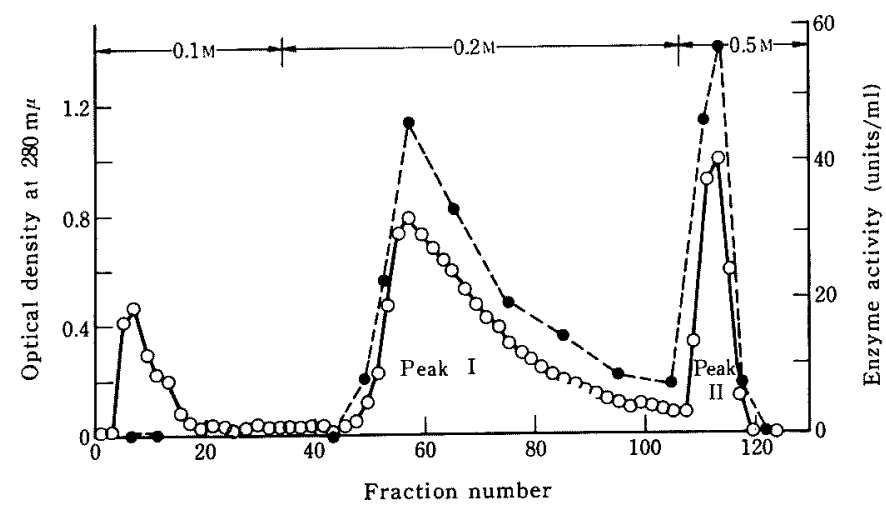

FIG. 1. Column Chromatography of Buckwheat $\alpha$-Glucosidase on Calcium Phosphate Gel.

- - Optical density at $280 \mathrm{~m} \mu ;$--- Activity on maltose.

$300 \mathrm{mg}$ of protein was applied to a column $(3.3 \times 5 \mathrm{~cm})$ of Ca-phosphate gel, equilibrated with $0.1 \mathrm{M}$ phosphate buffer ( $\mathrm{pH} 6.81$ ) and eluted step-wise with $0.1 \mathrm{M}, 0.2 \mathrm{M}$ and $0.5 \mathrm{M}$ phosphate buffer $(\mathrm{pH} 6.81)$. Fractions of $10 \mathrm{~g}$ were collected at a flow rate of $0.45 \mathrm{~g}$ per minute. Other details, see text. 

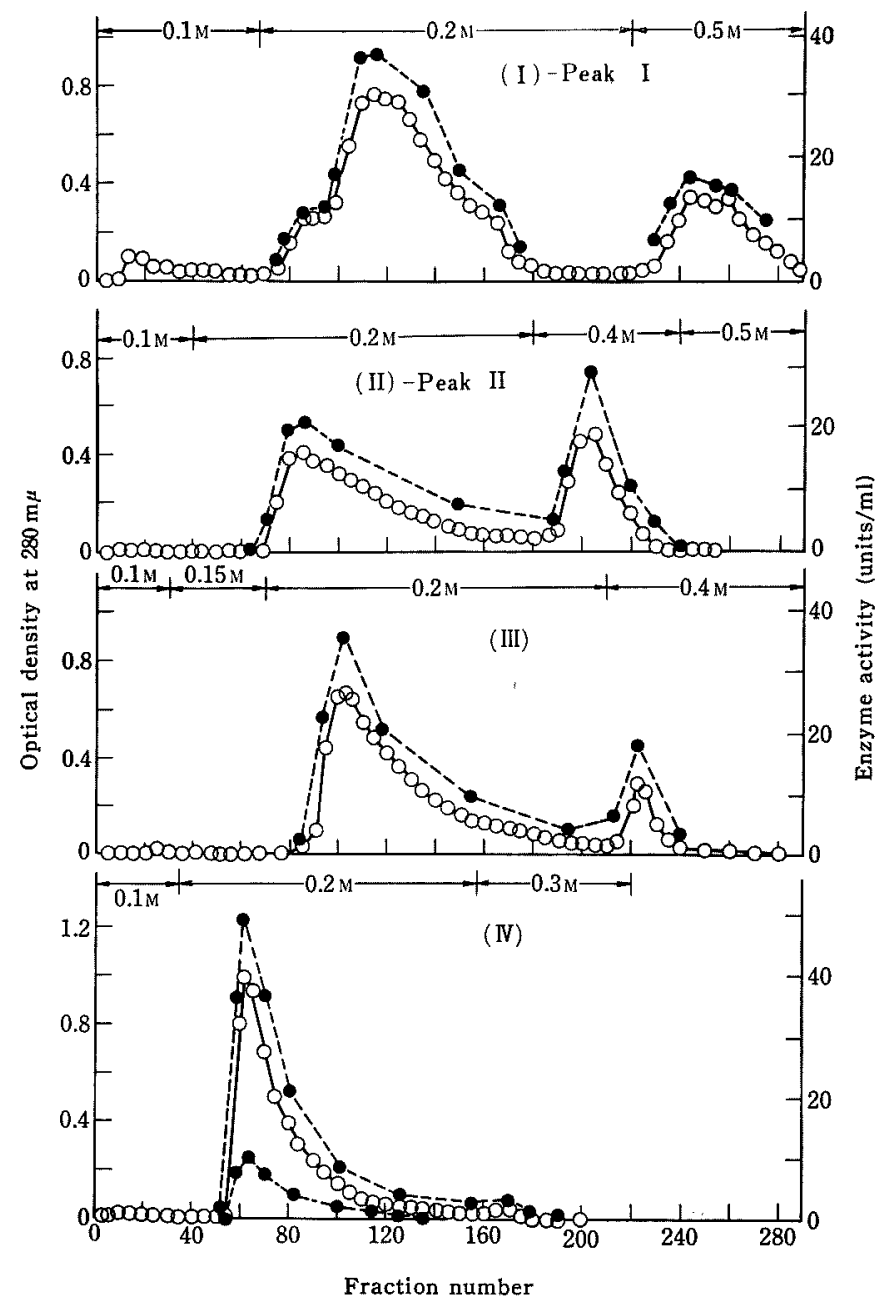

FIG. 2. Column Chromatography of Buckwheat $\alpha$-Glucosidase (Peak I and Peak II) on Calcium phosphate Gel.

\section{-O-: Optical density at $280 \mathrm{~m} \mu$; -.-๑--: Activity on maltose; \\ - - - Activity on soluble starch.}

Each protein (700 mg in case of (I), ca. $360 \mathrm{mg}$ in case of (II), $400 \mathrm{mg}$ in case of (III) and ca. $300 \mathrm{mg}$ in case of (IV)) was applied to a column $(3.3 \times 5 \mathrm{~cm})$ of Ca-phosphate gel (a column $(3 \times 4 \mathrm{~cm})$ in case of (II)), equilibrated with $0.1 \mathrm{M}$ phosphate buffer and eluted step-wise with $0.1 \mathrm{M}$, $0.2 \mathrm{M}, 0.3 \mathrm{M}, 0.4 \mathrm{M}$ and $0.5 \mathrm{M}$ phosphate buffer $(\mathrm{pH} 6.81)$. Fractions of $10 \mathrm{~g}$ were collected at a flow rate of $0.3 \mathrm{~g} \sim 0.5 \mathrm{~g}$ per minute. Other details, see text. In (I), (II) and (III), amylase activity was omitted.

graphed on calcium phosphate gel once again (Fig. 2-(III)). Further chromatographic treatment of the first peak (fraction No. $90 \sim 160$ ) in Fig. 2-(III) gave rise to a single peak, as is shown from Fig. 2-(IV). The activities of that single peak on maltose and soluble starch were 
TABle I. PuRification of Buckwheat $\alpha$-Glucosidase

\section{Procedure*1}

(A) Original Supernatant

(B) CM-cellulose Extract

134000

(C) Dialysate of ppt. with $\left(\mathrm{NH}_{4}\right) \mathrm{SO}_{4}$ (0.65 saturation)

(D) Ca-phosphate Gel Extract

(E) Filtrate of ppt. with $\left(\mathrm{NH}_{4}\right) \mathrm{SO}_{4}$ (0.4 0.7 saturation)

(F) First Ca-phosphate Gel Column Fraction: Fig. I $\left\{\begin{array}{l}\text { Peak I } \\ \text { Peak II }\end{array}\right.$

(G) Fourth Ca-phosphate Gel Golumn Fraction: (Second Peak Fractions)*4 -

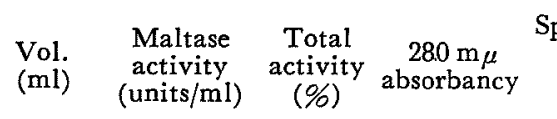

26000

5100

8700

$$
\begin{array}{ll}
2.05 \sim & 100 \\
2.96 & \\
7.21 \sim & 82.7
\end{array}
$$$$
12.6
$$$$
37.5 \sim
$$$$
51.4
$$$$
66.5
$$$$
22.5
$$$$
57.6
$$$$
10.95 \sim
$$$$
16.40
$$$$
1.22 \sim
$$$$
2.58 \sim
$$$$
2.68
$$$$
0.749
$$$$
97
$$$$
114.5
$$$$
\left.\begin{array}{l}
72214 * 2 \\
-\quad 27830 * 2
\end{array}\right\}
$$$$
30 .
$$

Specific activity $\mathrm{Hydrolytic}$ activity on maltose on maltose (units/OD at Hydrolytic activity $280 \mathrm{~m} \mu$ ) on soluble starch $\begin{array}{cr}280 \mathrm{~m} \mu \text { ) } & \text { on soluble st } \\ 0.182 & 4.2\end{array}$

$$
6.87
$$$$
16.87
$$

30.06

44.40

$\begin{array}{ll}32.5 & 25.8\end{array}$

$31057 * 2$

$(10167)^{* 2}$

$9.4580 * 3$

52.14

52.51

4.05

3.95

53.72

4.02

(3.1) (195)*3

(52.14)

*1 Sign of alphabet corresponds to the sign in the section of purification of buckwheat $\alpha$-glucosidase.

*2 Total maltase activity (units).

*3 Total Absorbancy at $280 \mathrm{~m} \mu$.

*4 Each second peak in Fig. 2-(I), (II) was combined.

in good agreement with absorbancy at $280 \mathrm{~m} \mu$. Combined fractions of second peaks in Fig. 2(I) and (II) also showed the same activities on each substrate as the fraction of a single peak in Fig. 2-(IV).

The procedure of purification and yield of $\alpha$-glucosidase are summarized in Table I, which showed about 300 -fold increase in specific activity for maltase activity. During these processes some other procedures were attempted as a trial for purifying this enzyme solution, as follows. Column chromatography on CM-Sephadex equilibrated with $0.1 \mathrm{~m}$ acetate buffer ( $\mathrm{pH} \mathrm{5.0)} \mathrm{was} \mathrm{tried} \mathrm{to} \mathrm{purify} \mathrm{the} \mathrm{enzyme}$ solutions in Fig. 1, which were dialyzed aganist the same buffer. As a result the enzymes adsorbed on CM-Sephadex were eluted with $0.5 \mathrm{~m}$ acetate buffer showing only one peak, in which activities on both maltose and soluble starch existed closely together with a certain ratio. Therefore, as described previously, column chromatography on CM-Sephadex was applied in order to concentrate the enzyme solution in Figs. 1 and 2 by eluting with a higher concentration of buffer, that is, $0.5 \mathrm{~m}$ acetate buffer containing $0.1 \mathrm{M} \mathrm{NaCl}$. After the procedure (E) in Table I it was found that the enzyme solution showed a single sharp peak of OD at $280 \mathrm{~m} \mu$ in good agreement with maltase activity on column chromatography of Sephadex G-75, G-100 and G-200 respectively. Fractionation with ammonium sulfate caused a considerable inactivation of purified enzyme solution obtained by procedure $(F)$ and $(G)$ in Table I. DEAE-cellulose treatment led to the inactivation of enzyme. It was also found that the enzyme was adsorbed irreversiblly by celite.

Evidence that the activity on starch was not due to the contamination of amylase was obtained by comparing the ratio of maltase activity to amylase activity during the purification process (Table I). The data show that the ratio of enzymatic activities to two kinds of substrate remained constant. Moreover, the identical behavior of the hydrolytic activity on maltose and soluble starch which was observed throughout all procedures of column 
chromatography seems to provide strong support for the presumption that both activities are attributed to a single enzyme. Therefore, the single peak of Fig. 2-(IV) was concentrated with CM-Sephadex column chromatography, dialyzed against $0.1 \mathrm{M}$ acetate buffer ( $\mathrm{pH} 5.0$ ) and used as the purified $\alpha$-glucosidase preparation hereafter. The concentrated enzyme solution was diluted with $0.1 \mathrm{~m}$ acetate buffer ( $\mathrm{pH}$ 5.0) according to reaction condition.

\section{Sedimentation analysis and electrophoretic analysis}

Homogeneity of the enzyme solution was investigated by sedimentation analysis with a Spinco Model E Ultracentrifuge. The final enzyme solution showed one peak. And at the process of first column chromatography with calcium phosphate gel each enzyme fraction (Peak I or Peak II in Fig. 1) was already found to show a single peak, as shown in Fig. 3. The concentrated enzyme solutions by GM-Sephadex treatment were dialyzed against $0.1 \mathrm{M}$ acetate buffer $(\mathrm{pH} 5.0)$ at $4^{\circ} \mathrm{C}$ for two days and applied to the analysis at $56,100 \mathrm{rpm}$ at $20^{\circ} \mathrm{C}$. The sedimentation coefficient, $s_{20}, w$ of the enzyme was calculated by the method described by Schachman ${ }^{191}$ and was corrected to that at $20^{\circ} \mathrm{C}$ in water according to the method of Svedberg. ${ }^{20)}$ The values for Peak I and Peak II in Fig. 3 were 5.67s and $5.79 \mathrm{~s}$ respectively and in either case about 6.1 s was obtained as the corrected value.

The electrophoretic analysis using the moving-boundary method was carried out with the final purified enzyme solutions. Each enzyme solution (Fraction of Fig. 2-(IV) and second peak fractions; Procedure (G) in Table I) was dialyzed against $0.1 \mathrm{~m}$ acetate buffer $(\mathrm{pH}$ 5.0) for 2 days at $4^{\circ} \mathrm{C}$. The electrophoretic patterns of the enzymes after 110 min migration are shown in Fig. 4. The pattern of Fraction of Fig. 2-(IV) showed a main peak
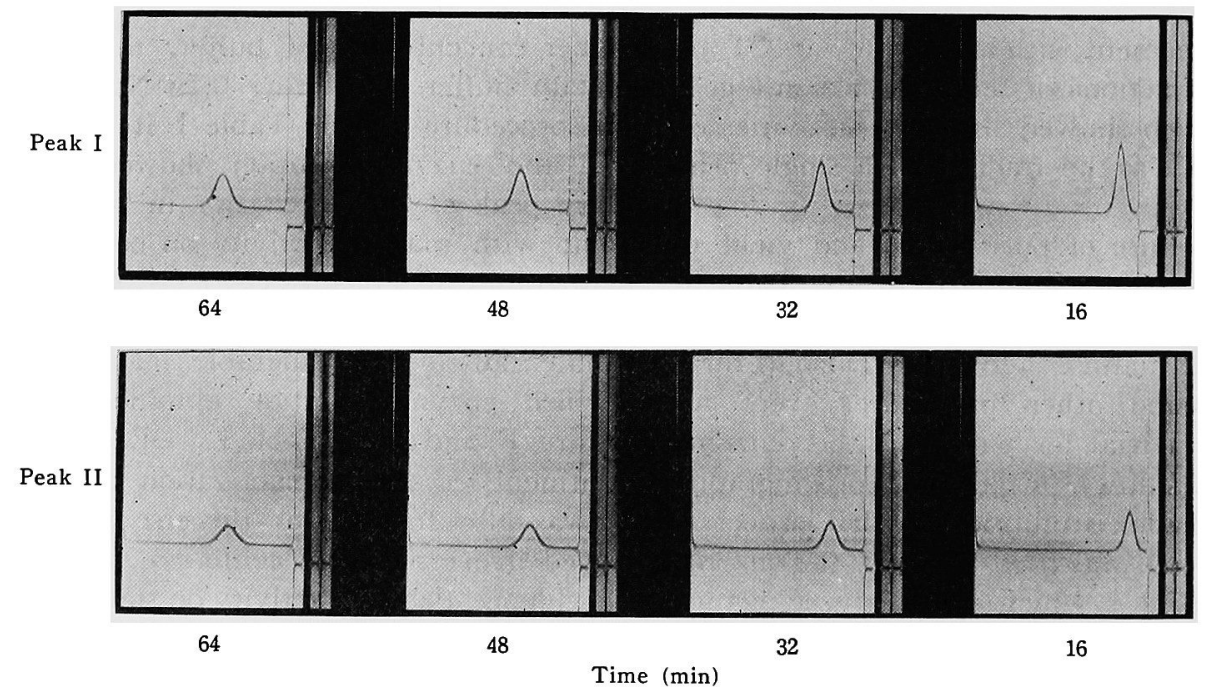

FIG. 3. Sedimentation Patterns of Buckwheat $\alpha$-Glucosidase (Peak I and Peak II in Fig. 1). $\mathrm{OD}$ at $280 \mathrm{~m} \mu$ of enzyme solution was 0.91 in the case of Peak I and 0.50 in the case of Peak II in $0.1 \mathrm{M}$ acetate buffer $(\mathrm{pH} 5.0)$; ionic strength, $\mu=0.10$. The photographs were taken at indicated times after reaching $56100 \mathrm{rpm}$. Temperature was $20^{\circ} \mathrm{C}$.

19) H. K. Schachman, "Method in Enzymology", (S. P. Colowick and N. O. Kaplan, eds.) IV, Academic Press Inc., New York, 1957, p. 32.
20) T. Svedberg and D. K. Pederson, "The Ultracentrifuge', Glearedon Press Inc., Oxford, 1940, p. 445 . 


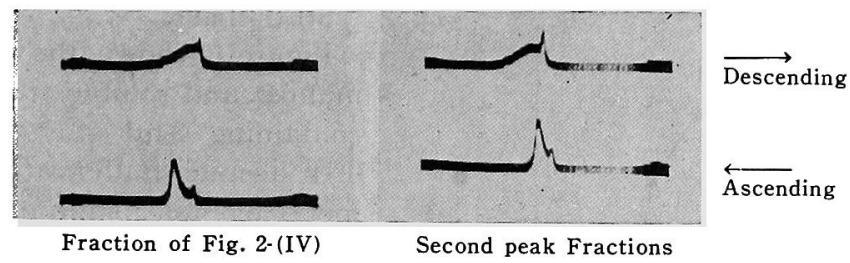

FIG. 4. Electrophoretic Patterns of Buckwheat $\alpha$-Glucosidase (Fraction of Fig. 2-(IV) and Second peak fractions: Procedure (G) in Table I).

The electrophoresis was carried out with $0.1 \mathrm{M}$ acetate buffer $\left(\mathrm{pH} 5.0\right.$ ) at $10 \mathrm{~mA}$ at $10^{\circ} \mathrm{C}$. OD at $280 \mathrm{~m} \mu$ of enzyme solution was Fraction of Fig. 2-(IV): 1.10 and Second peak fractions in Fig. 2-(I), (II): 0.90 . The patterns after $110 \mathrm{~min}$ of migration are shown.

and small peaks and second peak fractions also showed the similar plural peaks. The separation of these plural proteins into each single protein was unsuccessful under the experimental conditions adopted by the authors. Thus it is possible to say that purified $\alpha$ glucosidase showed one peak ultracentrifugally, but was heterogeneous in moving-boundary electrophoresis. It is not clear whether fractions of the second peaks in Fig. 2-(I) and (II) are the same enzyme as the fraction of peak in Fig. 2-(IV) or not. This problem will be examined in detail hereafter.

\section{pH-Stability}

The effect of $\mathrm{pH}$ on the stability of purified $\alpha$-glucosidase was investigated and the result is shown in Fig. 5. After a mixture containing $0.5 \mathrm{ml}$ of enzyme solution and $3 \mathrm{ml}$ of $0.1 \mathrm{M}$ acetate buffer or $1 / 15 \mathrm{M}$ phosphate buffer at various $\mathrm{pH}$ was kept at $30^{\circ} \mathrm{C}$ for $24 \mathrm{hr}$, the remaining activity was determined. The reaction mixture was composed of $1 \mathrm{ml}$ of the enzyme solution treated as above, $2 \mathrm{ml}$ of $0.1 \mathrm{M}$ acetate buffer (pH 5.0 ) and $2 \mathrm{ml}$ of $1 \%$ substrate. After the mixture was incubated for $10 \mathrm{~min}$ at $37^{\circ} \mathrm{C}$, the amount of glucose was determined by the modification of Somogyi's copper reagent method. The range of $\mathrm{pH}-$ within which the enzyme was stable under the condition described above was the same (4 to 7.3) when either of the substrates, maltose or soluble starch, was used.

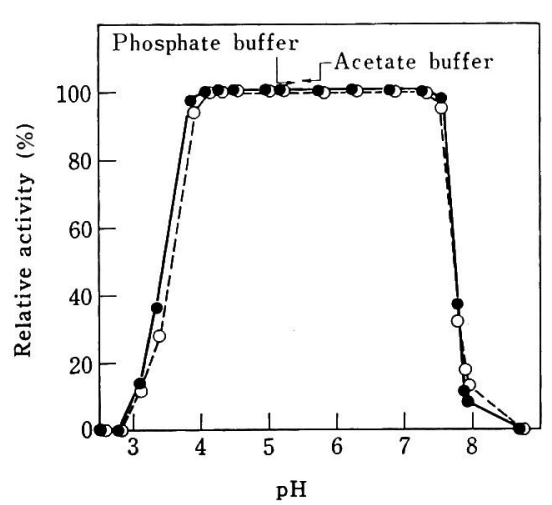

FIG. 5. Effect of $\mathrm{pH}$ on the Stability.

-1-: Activity on maltose

-----:- Activity on soluble starch.

Reaction conditions: see text.

\section{Temperature-stability}

The effect of temperature on the stability of purified $\alpha$-glucosidase was examined at various temperatures, as shown in Fig. 6. Two $\mathrm{ml}$ of $0.1 \mathrm{M}$ acetate buffer ( $\mathrm{pH} 5.0$ ) was kept at various temperatures for $10 \mathrm{~min}$ and to this was added $1 \mathrm{ml}$ of enzyme solution. After $10 \mathrm{~min}$ incubation the mixture was cooled and the remaining activity was determined as described in the section of $\mathrm{pH}$-stability. The enzyme was stable below $45^{\circ} \mathrm{C}$ for $10 \mathrm{~min}$ on both substrates.

The effect of time of incubation at $60^{\circ} \mathrm{C}$ was examined, as shown in Fig. 7. One ml of $0.1 \mathrm{M}$ acetate buffer $(\mathrm{pH} .5 .0)$ was kept at 


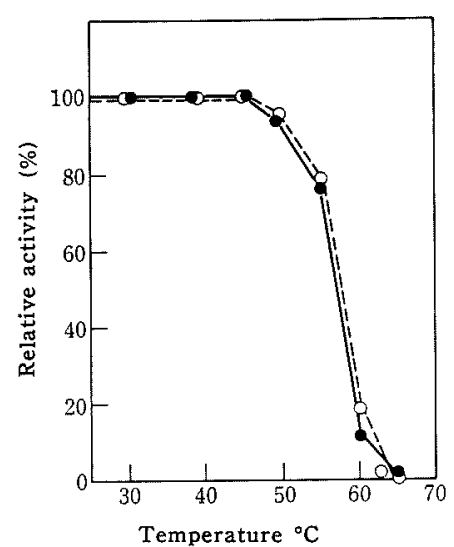

FIG. 6. Effect of Temperature on the Stability.

-1-: Activity on maltose

----: Activity on soluble starch.

Reaction conditions: see text.

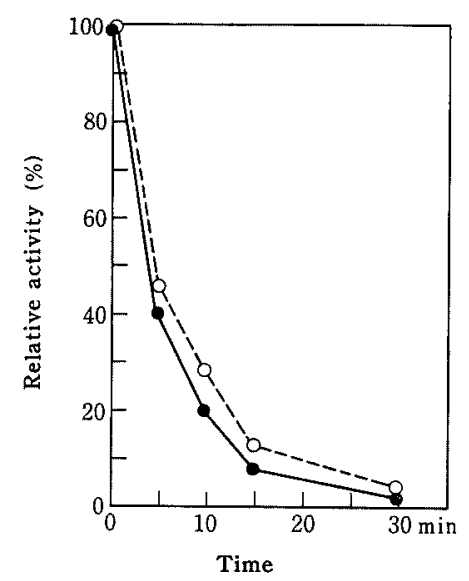

FIG. 7. Effect of Temperature $\left(60^{\circ} \mathrm{C}\right)$ and Time on the Stability.

-1: Activity on maltose

--O--: Activity on soluble starch.

Reaction conditions: see text.

$60^{\circ} \mathrm{C}$ for $10 \mathrm{~min}$ and to this was added $1 \mathrm{ml}$ of enzyme solution. After incubation for 5 $30 \mathrm{~min}$ at $60^{\circ} \mathrm{C}$ the mixture was cooled and the remaining activity was determined as described in the preceding section. The enzymatic activities both on maltose and soluble starch were decreased in the same manner and almost lost after $30 \mathrm{~min}$.

\section{pH-Optimum}

Figure 8 shows the $\mathrm{pH}$-activity curves on maltose and soluble starch. After a mixture containing $2 \mathrm{ml}$ of $1 \%$ substrate and $2 \mathrm{ml}$ of $0.1 \mathrm{M}$ acetate buffer at various $\mathrm{pH}$ was preincubated for $10 \mathrm{~min}$ at $37^{\circ} \mathrm{C}, 1 \mathrm{ml}$ of enzyme solution was added and the activity was determined. The $\mathrm{pH}$ optimum was 5.0 on both substrates.

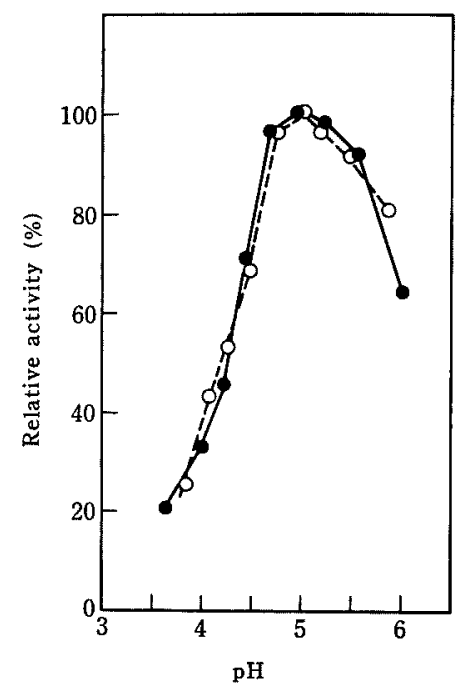

FIG. 8. Effect of $\mathrm{pH}$ on the Activity.

---: Activity on maltose

----: Activity on soluble starch.

Reaction conditions: see text.

\section{Temperature dependence}

Figure 9 shows the temperature-activity curves on maltose and soluble starch. After a mixture containing $2 \mathrm{ml}$ of $1 \%$ substrate and $2 \mathrm{ml}$ of $0.1 \mathrm{M}$ acetate buffer ( $\mathrm{pH} 5.0$ ) was preincubated for $10 \mathrm{~min}$ at various temperatures, $1 \mathrm{ml}$ of enzyme solution was added and the activity was determined. Optimum temperature was ca. $52^{\circ} \mathrm{C}$ on both substrates.

As is known from Fig. 5-Fig. 9, these properties were perfectly identical with both substrates. These results support the possibility that both maltase activity and amylase activity are due to a single enzyme. 


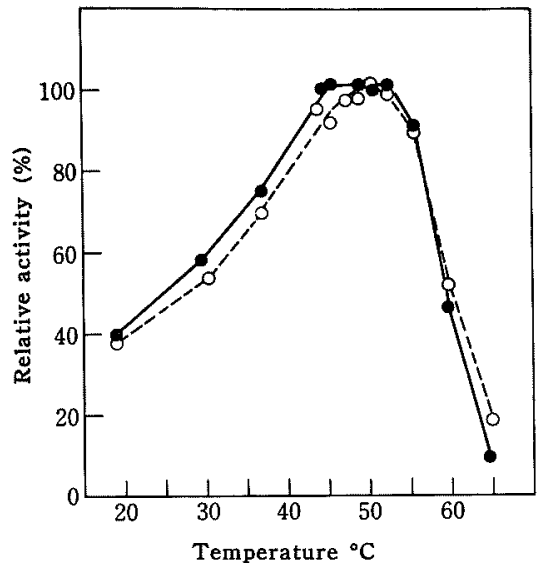

FrG. 9. Effect of Temperature on the Activity.

$$
\begin{aligned}
& \text {-1 Activity on maltose } \\
& \text { Reaction conditions: see text. }
\end{aligned}
$$

Effect of substrate concentration on the rate of enzyme action

The enzyme concentration was kept constant and the relation between the velocity and the concentration of substrate was examined on maltose and soluble starch, as shown in Fig. 10. The reaction mixture consisting of $0.05 \mathrm{ml}$ enzyme solution, $0.95 \mathrm{ml}$ of $0.1 \mathrm{M}$ acetate buffer

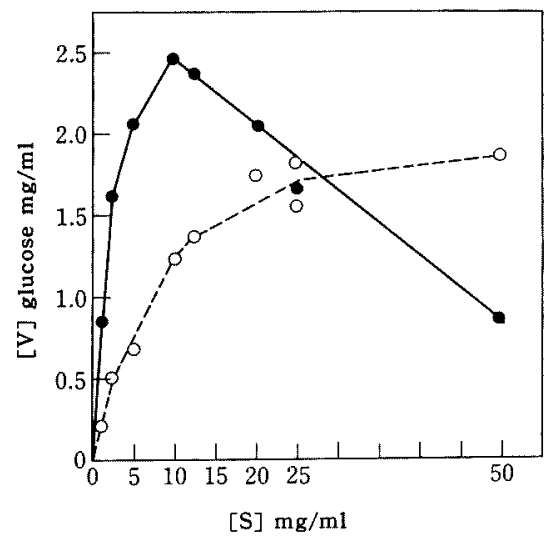

FIG. 10. Relation between Initial Velocity and Substrate Concentration.

- - Activity on maltose

------: Activity on soluble starch.

Reaction conditions: see text.
(pH 5.0) and $1 \mathrm{ml}$ of substrate solution of various concentrations was incubated for $10 \mathrm{~min}$ at $37^{\circ} \mathrm{C}$ and the amount of glucose produced was determined. When maltose concentration exceeded ca. $1 \%$, the initial velocity of hydrolysis was lower than could be predicted from the Michaelis-Menten equation. It seemed that transglucosylation may be the cause of the "substrate inhibition", since maltase activity was measured by the increase of reducing power. A similar observation has been made with intestinal glycosidases. ${ }^{21}$ On soluble starch no "substrate inhibition" could be demonstrated.

The relationship between the time course of the reaction and substrate concentration was examined with both substrates, as shown in Fig. 11 . In case of $0.5 \%$ substrate concentration, the reaction mixture containing $10 \mathrm{ml}$ of $1 \%$ substrate, $9.5 \mathrm{ml}$ of $0.1 \mathrm{~m}$ acetate buffer $(\mathrm{pH} 5.0)$ and $0.5 \mathrm{ml}$ of enzyme solution was incubated at $37^{\circ} \mathrm{C}$ for $24 \mathrm{hr}$. At definite intervals $2 \mathrm{ml}$ of the mixture was applied to the

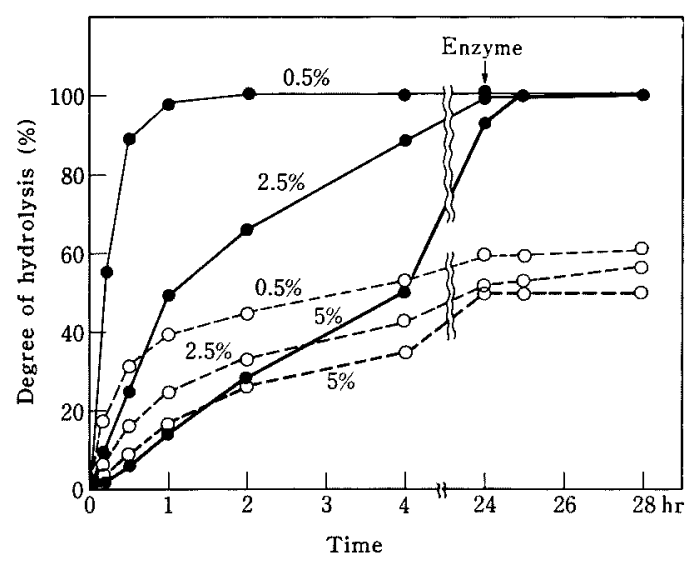

FIG. 11. Effect of Substrate Concentration on Degree of Hydrolysis.

$$
\begin{aligned}
& \text {-1:- Activity on maltose } \\
& \text { Reaction conditions: see text. }
\end{aligned}
$$

21) A. Dahlquist, Acta Chem. Scand., 14, 1797 (1960). 
determination of degree of hydrolysis and at the same time a portion was examined for the reaction products by paper chromatography. After $24 \mathrm{hr} 0.1 \mathrm{ml}$ of enzyme solution was added to the reaction mixture and allowed to react for further $4 \mathrm{hr}$. In case of $2.5 \%$ and $5 \%$ concentration, the reaction mixture consisting of $5 \mathrm{ml}$ of $5 \%$ or $10 \%$ substrate, $4.75 \mathrm{ml}$ of $0.1 \mathrm{M}$ acetate buffer $(\mathrm{pH} 5.0)$ and $0.25 \mathrm{ml}$ of enzyme solution was incubated at $37^{\circ} \mathrm{C}$, being followed by the same treatment as in $0.5 \%$ substrate concentration, except for $0.5 \mathrm{ml}$ in place of $2 \mathrm{ml}$ of the reaction mixture. Although nearly complete hydrolysis of maltose was observed at any concentration, the degree of hydrolysis of soluble starch was in the range of $50 \sim 60 \%$ and iodine color remained blue. With a substrate concentration of $0.5 \%$, glucose was the sole sugar released from both maltose and soluble starch during the whole reaction time. However, in the concentration of $2.5 \%$ the formation of a small amount of several kinds of sugar from either substrate was recognized by the use of paper chromatography, besides glucose. With a concentration of $5 \%$, more different kinds of sugar were produced from each substrate, surely by transglucosylation reaction. Figure 12 shows the products from $5 \%$ substrates. It was found that most of transglucosylation products were hydrolyzed after $24 \mathrm{hr}$.

Further work is in progress on the details of substrate specificity and transglucosylation reaction of this enzyme and will be reported in the next paper.

Thus it has been known that buckwheat $\alpha$. glucosidase hydrolyzed both maltose and soluble starch to glucose and in the presence of high concentrations of each substrate exerts transglucosylation reaction. At present, the investigation of $\alpha$-glucosidase having such enzymatic properties just mentioned appears to be worked nearly with higher plant sources as written in the introduction. Accordingly the existence of

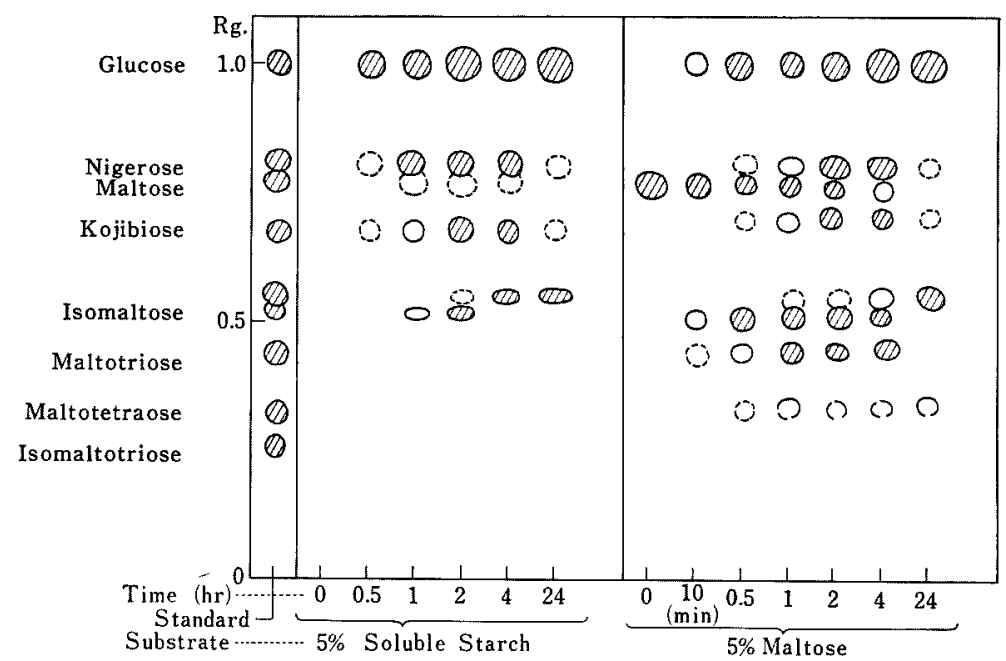

FIG. 12. Paperchromatogram of the Transglucosylation Products from $5 \%$ Substrates by Buckwheat $\alpha$-Glucosidase.

Experimental condition is the same as in Fig. 11.

22) T. Sawai, J. Biochem., 48, 382 (1960) 
a similar type of enzyme in Candida tropicalis assistance in the experimental work. The var. japonica ${ }^{221}$ will be noteworthy. authors are indebted to Mr. Seiya Chiba for his helpful advices and to Mr. Yoshiya Niki Acknowledgment. Thanks are given to Mr. for his electrophoretic analysis. Hajime Yokota and Mr. Haruki Rai for their 